\title{
Scientific Modelling of Decorative and Applied Arts of the Indigenous Small-Numbered Peoples of the Krasnoyarsk Territory: Current State and Ways of Effective Development
}

\author{
Maria A. Kolesnik and Alexandra A. Sitnikova* \\ Siberian Federal University \\ 79 Svobodny, Krasnoyarsk, 660041, Russia
}

Received 01.06.2017, received in revised form 02.10.2017, accepted 09.10.2017

\begin{abstract}
The article presents a scientific model of the traditional functioning of the decorative and applied arts of the indigenous peoples of the Krasnoyarsk Territory (Krai). This is an "ecological model", since it implies careful and economical use of all natural resources being extracted. The current state of the decorative and applied arts of the indigenous small-numbered peoples of the Krasnoyarsk Territory North is described by a scientific model, which is perceived as a "model of symbolic consumption". The authors analyzed main types of souvenirs produced by the indigenous minorities of the North of the Krasnoyarsk Territory, namely beadwork, bone carving works, festival clothes, taxidermy items, shaman attributes, doll amulets, etc. The researchers offered a scientific model of ways to develop the decorative and applied arts of the indigenous small-numbered peoples the Krasnoyarsk Territory North. These include the improvement of the "symbolic consumption" system first at the level of souvenir production, then at the level of creating ethnocultural villages and ethnic parks, and, finally, at the level of creating contemporary art works to be understandable and interesting internationally.
\end{abstract}

Keywords: decorative and applied arts, the indigenous small-numbered peoples, souvenirs of the indigenous peoples of the North, ethnic park, development models for the decorative and applied arts of the indigenous peoples of the North.

The reported study was funded by Krasnoyarsk Region Science and Technology Support Fund (the research project "Decorative and applied arts of the Indigenous Peoples of the Krasnoyarsk Territory: Current Status, Prospects for Development").

The reported study was funded by Russian Foundation for Basic Research, Government of Krasnoyarsk Territory, Krasnoyarsk Region Science and Technology Support Fund (the research project № 17-16-24601).

DOI: 10.17516/1997-1370-0150.

Research area: culturology.

(C) Siberian Federal University. All rights reserved

* Corresponding author E-mail address: kolesnik_ma@bk.ru; sem_dobrianka@mail.ru 


\section{Introduction}

Under the conditions of the increased attention to the culture of the indigenous smallnumbered peoples living in the Krasnoyarsk Territory (Krai), and first of all, to the culture of the indigenous peoples who live in the north of the region, coupled with the need to preserve in a globalizing world local, original and unique cultures, which are on the verge of extinction due to the onslaught of civilization, we think it necessary to make an analysis of the decorative and applied works of these people as an integral part of this culture. Studying the experience of harmonious interaction of man and nature is manifested in the best way in these forms of art being the integral part of the indigenous smallnumbered peoples' culture. To date, arts and crafts have been exhaustively studied; there are catalogues and monographs describing the decorative and applied practices of certain ethnic groups in the Krasnoyarsk Territory, e.g. how the Evenks, the Dolgans, the Nganasans, the Nenets people and the Selkups sewed clothes, etc. The applied art of certain ethnic groups is covered in literature more extensively (e.g. the Evenk decorative and applied creative works), while the decorative and applied works of other ethnoses (e.g. the Selkups) has not been fully studied. The present research is aimed neither at describing the decorative and applied art system of indigenous small-numbered peoples of the Krasnoyarsk Territory North nor at the analysis of individual works, but at scientific modelling the current state of the decorative and applied arts of these peoples and the development prospects.

\section{Methods and materials}

The research is based on the results of expeditions to Yessei village where the indigenous small-numbered people (the Yessei Yakuts) live and to the Turukhansk region where the Selkups live. In addition, the study is backed up by a thorough analysis of literary sources (monographs, catalogues and articles describing the current state of decorative and applied arts of the indigenous small-numbered peoples of the Krasnoyarsk Territory; reports of research teams following studying the culture of the indigenous small-numbered peoples of the Krasnoyarsk Territory; diaries of expeditions to the villages where the Krasnoyarsk Territory indigenous minorities have settled (Nosok, Surinda, Farkovo, Dudinka, Khatanga, etc.).

\section{Literature review}

According to the article's logic, for the beginning it is supposed to make a review of the literature devoted to the actual state of decorative and applied arts of the indigenous smallnumbered peoples of the Krasnoyarsk Territory, and then to turn to studies describing the world practice of developing the indigenous population art.

The current state of decorative and applied arts of the indigenous peoples inhabiting the Krasnoyarsk Territory has been thoroughly described and evaluated. A lot of scientists publish articles and monographs devoted to this topic regularly.

For example, N.N. Pimenova (Pimenova, 2014) explores how the transformations of the traditions of the Krasnoyarsk Territory indigenous peoples have influenced the present state of their arts and crafts. In particular, the author notes that folk art forms are mainly realised as souvenirs, or motifs, plots, techniques and national flair, which penetrate into the professional creativity sphere. In addition, the article underlines the role of Soviet practices in preserving and developing decorative and applied arts and mentions the real forms of this process as well.

Many authors study bone-cutting art of the indigenous peoples of the North. N.M. Libakova (Libakova, 2015) and a number of other scientists 
analyze the works of the Krasnoyarsk Territory bone-cutting masters. It shall be noted that in the earlier article G.N. Rodionov (Rodionov, 2007) said nothing about the masters of this region; he even states that "at present bone-cutting art exists only in several regions - in Alaska, Yakutia and Chukotka". By them, of course, we mean the prominent and well-established bone carving schools, whereas the recent scientific works about the Krasnoyarsk Territory craftsmen show that at the moment traditional art is reviving and a new school representing the Evenki, Nganasan and Dolgan ethnic groups' art takes off.

G.N. Varavina (Varavina, 2016) conducts a semiotic and linguistic analysis of the traditional Even and Evenk ornament and concurrently discusses its modern application in arts and crafts and possible use in design.

Siberian scientists N.P. Koptseva, V.I. Kirko, N.M. Libakova, K.V. Reznikova, K.V. Sertakova, N.N. Pimenova, A.V. Kistova, A.A. Semenova (Koptseva et al., 2012) and others actively explore the culture and art of the indigenous smallnumbered peoples of the Krasnoyarsk Territory under conditions of global transformations.

A large block of research is devoted to the role of arts and crafts in forming and preserving ethnic identity of the representatives of smallnumbered nations. For example, N.P. Koptseva, N.N. Pimenova, N.N. Seredkina (Koptseva et al., 2013) consider the Evenki art as one of the most important factors for creating positive all-Russian identity, at the same time touching upon the topical problems in the contemporary folk art sphere. On the example of the Khakas masters' art N.P. Koptseva and N.N. Nevol'ko (2012) reveal the uniqueness of the ethnic culture of the Siberian indigenous small-numbered peoples. V.A. Kudashkin and S.A. Kiryutkin (2016) highlight the participation of the Siberian artistic intelligentsia in the development and popularization of ethnic culture. The authors describe the contribution of some masters, such as specialists in bone carving N.N. Kirgizov and A.N. Chunanchar, an embroidery master S.S. Aksenova. In general, their article is devoted to the description of the selfless activity of the representatives of the indigenous peoples in the field of folk art preservation and development in a difficult in many respects post-Soviet period.

T. M. Lomanova (Lomanova, 2015) raises a question that is relevant for contemporary decorative and applied arts, connected with the authenticity of the works created today. The author also gives a detailed analytical overview of the contemporary masters' artworks which follow traditions of different peoples: the Dolgans, the Nganasans, the Evenks, the Khakass people and others.

Description of the traditional art of many indigenous peoples of the North is provided in the Z.I. Ivanov-Unarov's monograph (2005).

In terms of studying applied practices on the development of arts and crafts the article by N.V. Zolotarev, T.S. Kurianova, O.M. Ryndin (2013) is of particular interest. The main attention is paid to the project activities on the basis of regional museums, as well as to the various festivals, aimed at preservation of arts and crafts and mass attraction.

There are few articles devoted to the analysis of the current state of the decorative and applied arts of the indigenous peoples and the development prospects. Among them, we can name a study by N.I. Vukvukay (Vukvukay, 2012), dedicated to the contemporary arts and crafts of the Chukotka indigenous peoples. In particular, the article describes the practices that contribute to the further development of art, for instance, the formation of an educational environment targeted at training professional artists, the development of business projects aimed at selling souvenirs and artworks, creating special spaces and events for exhibitions. 
S.A. Sorokina and S.L. Chernyshova (Sorokina, Chernyshova, 2014) characterise the activities of the RSPU named after A.I. Herzen, where many representatives of the indigenous minorities have been studying. Back in the Soviet Union and in the Russian Federation, this university has been the centre promoting the preservation of the indigenous peoples' culture, enriching it with new intellectual forces through a comprehensive educational process. Most notably, the university realizes an ethnic and cultural model of education, developed by I.L. Nabok, so that students have the opportunity to learn arts and crafts at a professional level.

\section{E. Zulaikha, M. Brereton (Zulaikha,} Brereton, 2011), using the example of traditional crafts in Indonesia, take into account innovative strategies for souvenirs, and as a reference point the authors offer to use those strategies that are practiced in the fashion industry. E.E. Totonova (Totonova, 2015) depicts the experience of the indigenous peoples of Canada, where small enterprises oriented towards the traditional culture of the inhabitants determine the economic processes in the region. The author believes that this experience of the indigenous peoples' organization can be useful in the Russian Federation.

\section{Scientific modelling of the contemporary state of arts and crafts of the indigenous small-numbered peoples of the Krasnoyarsk Territory}

The main goal of the study is to present models of the current state of the decorative and applied arts of the indigenous small-numbered peoples of the Krasnoyarsk Territory North and development prospects. Initially, it is necessary to identify specific indigenous small-numbered peoples whose decorative and applied artworks were in the centre of attention while we were building our scientific models. These peoples are the Evenks, the Dolgans, the Nganasans, the Nenets, the Selkups and the Yessei Yakuts. The main types of decorative and applied arts of these peoples are mostly the same - sewing traditional winter and summer clothes, fur products (parkas, winter coats, having different names in each language, boots, mittens, etc.); beadwork (used in decoration of everyday and ritual clothes, making jewellery for women and souvenirs); bone carving; woodcarving, taxidermy; the manufacture of household items, items of female handicraft and male hunting tools (dishes; kumalans (low seats in the Tungus chums, covered with skins); pin cushions; bags for needlework, powder; sheath, etc.), sewing dolls, making bead decorative panels. It should be noted that each nationality has developed certain types of arts and crafts to a greater or lesser extent, but almost all of them have been saved from the past, so we can say that beadwork is more developed in Evenkia, while the Dolgans have mastered bone-cutting skill. At the same time, the art of the indigenous smallnumbered peoples of the Krasnoyarsk Territory has one common trait: everything started with the economical and full-fledged development of natural resources, primarily the materials of the animal world (deer, northern birds, dogs, rabbits, squirrels, etc.). It is obvious that such animal as a deer is the central source for creating decorative and applied artworks by the indigenous smallnumbered peoples of the Krasnoyarsk Territory North. In addition to the fact that venison is a source of food and a deer is treated as a transport means by the northern peoples, each part of a deer is used economically and environmentally friendly by the northern peoples: its fur is used for tailoring (metaphorically speaking, a person dressed in the traditional northern clothes becomes a deer himself); its hair is used for making ornaments and sewing; the veins used to be turned into threads; the bones were carved artistically; earlier, when the Krasnoyarsk 
Territory North did not use trade glass beads, the beads had been made from deer bones (and from shells); horns serve the prototype for most ornaments covering ornaments and household items. As a result of this idea aboutthe natural origin of the decorative and applied arts of the northern peoples, we will present the first model of the traditional decorative and applied arts of the indigenous peoples of the Krasnoyarsk Territory, which can be called "ecological", since it is based on the economical and careful use of absolutely all the nature by the northern peoples. Prior to this, it is necessary to state the fact that while drawing up this model we relied mostly on a holistic and systemic view of the Evenki arts and crafts, which was fully explored by N.N. Pimenova (Pimenova, 2014), who wrote the book "Masters of Evenkia. Creative Heritage" and articles on this matter, but, as already said, the decorative and applied arts of the peoples of the Krasnoyarsk Territory North can be considered as a united creative space where some nations have been developing all the distinctive types of folk art with various types prevailing.

This first model (Fig. 1) is necessary for understanding the origins of the decorative and applied creativity of the indigenous northern peoples. Partly it can be called an ontological model, since it represents the essence and existence of the indigenous peoples' decorative and utilitarian object world. This existence consists in maximizing the use of all the natural resources. Today, masters and craftspeople from among the indigenous peoples of the North often express regrets that their art is losing its utilitarian importance, and researchers and scientists say that for the further development of the decorative and applied arts of these peoples it is very important to return the utilitarian value to the works created by craftsmen. The reason for this is that the origin of their decorative and applied arts is connected with the need to "put into action" and in some way use everything that is got as a result of the man and nature interaction. People tried to use

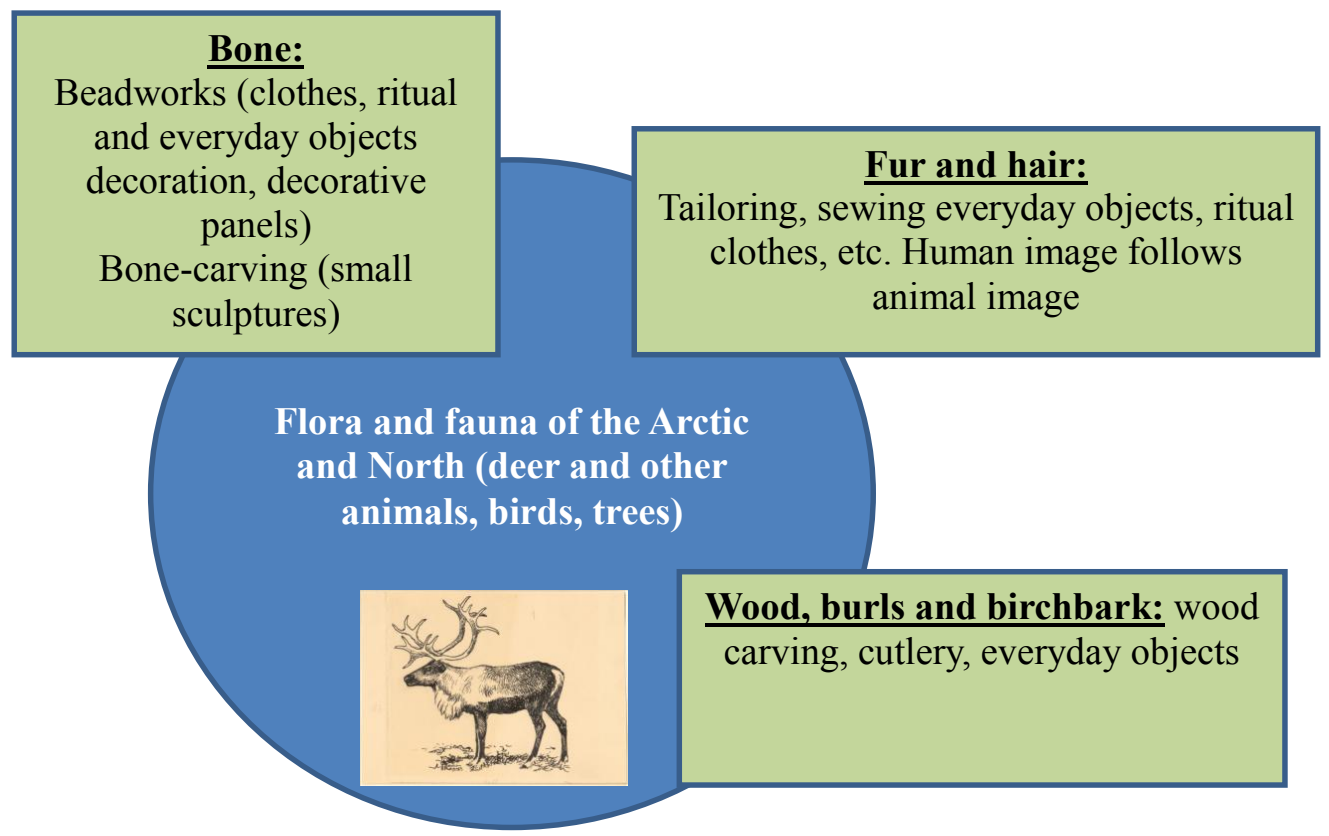

Fig. 1. Model 1. Ontological model of decorative and applied arts of the indigenous small-numbered peoples of the North of the Krasnoyarsk Territory - "Ecological model" 
bones for decoration and ritual ceremonies, fur for sewing, wood to surround themselves with useful things in everyday life, and, as noted in the N.N. Pimenova's study (Pimenova, 2014), wood for making utensils or home decor has also been used with care for nature. These are wood parts from burls which hinder the trees growth or diseased parts of a tree. We may even assume that environmental friendliness and thrift in relation to natural resources accompanying the creative activity of the indigenous northern peoples can become the dominant direction that will allow this type of art to develop successfully further. At the same time these masters can teach arts and crafts to other peoples living nearby and who nowadays face the problem of the need to make their way of life less aggressive in relation to nature.

From the first model, reflecting the basic properties of the decorative and applied arts of the indigenous northern peoples, it is possible to move on to the next one, which is in the focus of the present research aimed at studying the contemporary state of decorative and applied arts of the indigenous small-numbered peoples of the Krasnoyarsk Territory.

Let us explain the second model (Fig. 2 ), which in general terms represents the contemporary state of decorative and applied arts of the indigenous small-numbered peoples of the Krasnoyarsk Territory North and not only because the dominant consumption culture is characteristic of the global post-industrial space. We propose to call it a "symbolic consumption model", as these days the art and craft practices of the northern peoples are oriented towards the souvenirs' creation. It is worth mentioning the fact that this model is rather tentative, as, firstly, some peoples of the Krasnoyarsk Territory North even today adhere to the basic traditional model of the decorative and applied works of art, that is, they make ethnic clothes and everyday objects for utilitarian consumption. Secondly, it is obvious that the tourism business, which is closely connected with the symbolic consumption of ethnic decorative and applied arts, is poorly developed in the Krasnoyarsk Territory North even if one compares it with other areas of residence of the indigenous small-numbered peoples (for example, as opposed to the YamalNenets and Khanty-Mansi Autonomous Okrugs, where there are ethnic villages and ethno-cultural tourism is actively developing there). Despite the stipulated conventions, many forms and options for the development of decorative and applied arts indicate that the symbolic consumption model is relevant for the Krasnoyarsk Territory North.

The presented scheme of polyvariant existence of works of arts and crafts elicits the main formats of "souvenir" production created by masters among the small-numbered peoples. The bone carving art of the Dolgans, the Nganasans, the Evenks and other northern ethnic groups is highly valued: bone carvers' works often become objects of museum collections, and are actively commodified, it means that they become objects of elite symbolic consumption, since bone carving is one of the most expensive types of decorative and applied arts of the northern peoples, which entails the possibility of creating bone-cutting workshops and production rooms, and the opportunity to promote the bone carving works by the means of modern marketing (creation of Internet sites where one can buy this production). From the point of view of tourism marketing shamanism also seems quite profitable due to the uniqueness and originality of traditional beliefs of the indigenous small-numbered peoples. Shamanism and shamanic attributes, being one of the important strongholds of mysticism in the modern rational world, often turn into attractive objects for commodification: shamanic masks, tambourines and shaman dolls lose their sacred meaning and are marketed. The experience 


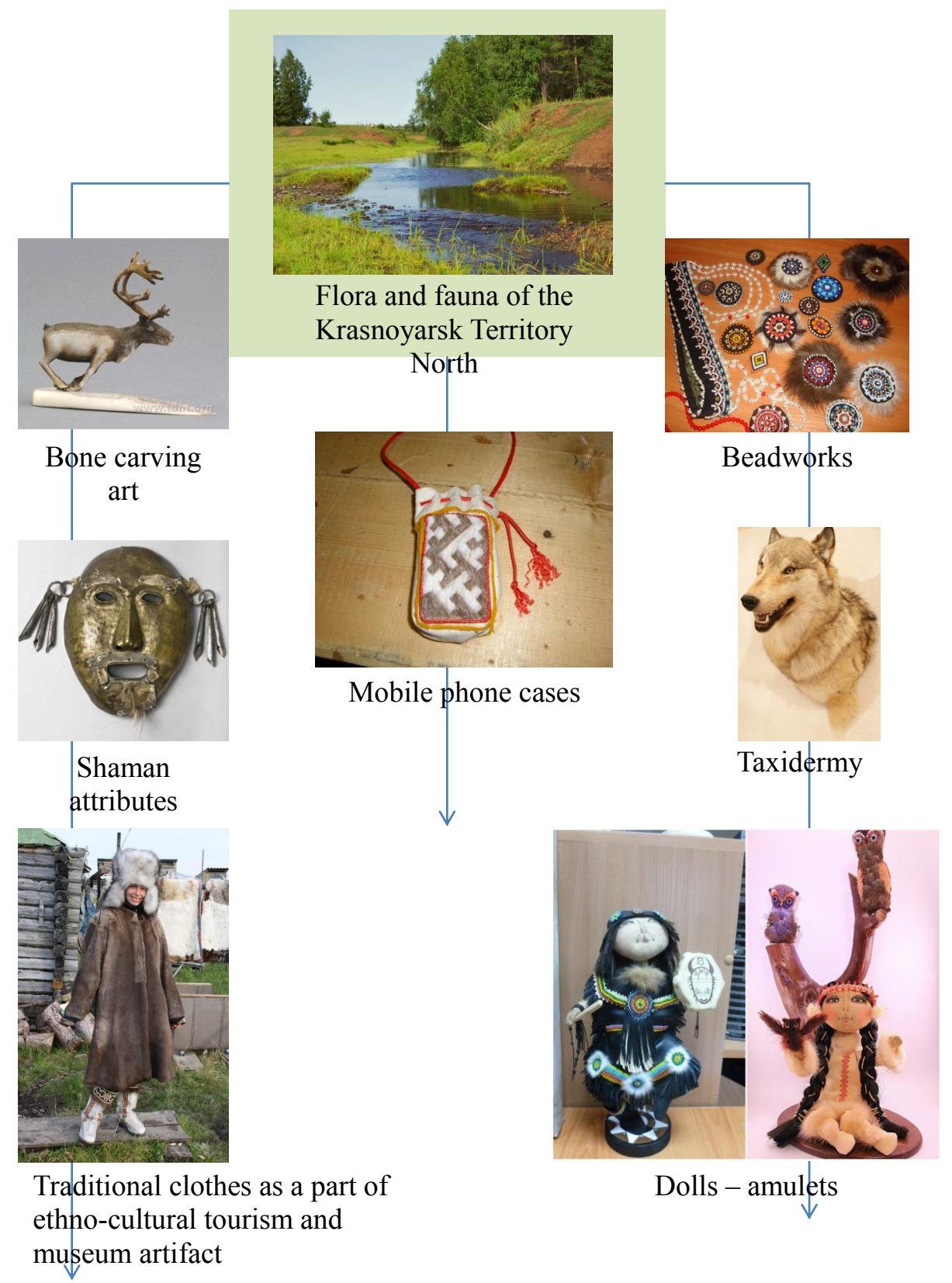

Fig. 2. Model 2. The current state of arts and crafts of the indigenous small-numbered peoples of the Krasnoyarsk Territory North. "Symbolic consumption model"

of such a reinterpretation of shamanism in contemporary arts and crafts is described in one of the few articles on the decorative and applied arts of the indigenous peoples of the Russian North (Gaidysheva, Parniakov, 2014), which exposes the creative production of the "dream catcher" work based on the Russian North shaman rituals and patterns as implemented by the students of the Institute of Art in one of the Russian universities. Such experience shows that one of the possible methods of the preservation of the decorative and applied arts of the indigenous northern peoples is including research and artistic processing of the authentic 
ethnic works of decorative and applied arts in the education of students who learn design or study in the institutions of culture and art. One of the most crucial and ubiquitous types of decorative and applied arts of the indigenous northern peoples has traditionally been tailoring, which refers to the manufacture of summer and winter fur garments, their embroidery and decoration with beads, festive ornaments, depending on the purpose of this type of clothes, whether these are everyday, ritual or festive clothes. Researchers and participants of expeditions to the north of the Krasnoyarsk Territory, to the places where the indigenous small-numbered peoples live, note the fact that so far the indigenous small-numbered peoples of the Krasnoyarsk Territory North have practically stopped wearing their ethnic clothes in the summer, preferring mass consumption goods, widespread everywhere, and in winter they have started to wear typical of the whole country winter clothes, while continuing to use their national clothes (especially it is true for those peoples who experience the processes of strengthening ethnic self-identification). Indeed, the preservation takes place as the indigenous small-numbered peoples of the North live in such harsh climatic conditions, which have no analogue in other regions of the country. Since today the demand for the use of ethnic clothes has obviously decreased, they have become a part of ethno-cultural tourism or museum exhibits. These tendencies gradually transform the national clothes of the indigenous small-numbered peoples of the North into the category of "elite symbolic consumption", as fur clothing and fur products like the Evenk kumalans, are extremely expensive souvenirs. Bead jewellery is popular and, on the other hand, it is more like mass souvenir production, which is specificity of many indigenous peoples of the north. These beadworks include amulets with solar symbols, decorative beaded panels with images of deer or even northern landscapes.
Bead jewellery performs the main function of souvenirs, which is to convey the impression of a certain geographical place the tourist visits, or to present this impression to those who have not been there, since they fix the main hallmarks of the northern land - the beauty of landscapes, the dominant place of deer in northern culture, the value of the sun in polar conditions and the like. It is noteworthy that today the indigenous small-numbered people practice taxidermy craft, making stuffed deer, bears, wolves and smaller representatives of northern fauna, which also have no utilitarian purpose. Finally, there is the curious development of the decorative and applied arts of the indigenous small-numbered northern peoples in such kinds of production as sewing of dolls, doll amulets and manufacturing cases for mobile phones. As N.N. Pimenova points out (Pimenova, 2014), the Evenks did not initially make dolls for their children, the dolls were created only for shamanic rituals, so this ritual purpose of dolls for a long time did not let the Evenks make dolls for games. For the first time they saw the game doll in the beginning of the $20^{\text {th }}$ century after active contacts with Russian culture and started making dolls for children only in the Soviet period. If you look at today's Evenk dolls, which often represent the image of "a well-dressed northern girl", locally revered spirits and other characters, it is clear that these dolls do not have utilitarian value. Though these are the dolls for children games, they are made artfully, have high quality as expensive souvenirs with an image of people and spirits of the North, which again points to the fact that this kind of art is in line with the symbolic consumption model. The recent trend is the creation of cases for mobile phones made of beads, with traditional patterns - solar signs, twisted reindeer antlers, images of deer, loon paws, etc. We refer to this type of products in the modern decorative and applied arts of the indigenous peoples to draw 
a special attention to several aspects inherent in the decorative and applied arts of these peoples. Firstly, this is the steady aspiration of the indigenous northern peoples to find a utilitarian application to their artistic crafts; secondly, this is the inherent ability of the decorative and applied arts of the indigenous northern peoples to adapt to new conditions and assimilate new objects.

Having commented on each type of actual decorative and applied arts of the indigenous peoples of the Krasnoyarsk Territory North, let us turn to the very "symbolic consumption model". What is the reason for the transition of modern indigenous northern peoples to this model when creating the decorative and applied arts? Is this an indicator of "hollowing out", the gradual disappearance of unique folk arts and crafts of the indigenous peoples of the Krasnoyarsk Territory North, or is this a new step for the development of this art form? Today, a lot of research is devoted to the study of phenomenology and the axiology of souvenir products, but within the framework of this research we will turn only to one study which thoroughly highlights the problems of interest to us. This is the research by N.A. Barabanova "The functional essence of the tourist souvenir" (Barabanova, 2014), which concludes that: a) the increase in the number of souvenirs is associated with the phenomenon of modern tourist culture (in fact, the consumption of impressions from the world travel); a souvenir is a kind of descendant of the "conquering trophy", fixing the very fact of "conquering-visiting" a unique place, reflecting some characteristic feature of the place; b) souvenir products are natural for a postindustrial society, a consumer society, since a tourist trip should also be somehow materialized to clearly demonstrate the fact of a visit to a place; c) souvenirs have additional functions, for example, gratification to the government officials or "elite symbolic consumption", meaning collecting expensive souvenirs as a way to stand out as a unique consumer in the world of mass consumption. Thus, the answers to the above questions are the following: the indigenous smallnumbered peoples of the Krasnoyarsk Territory North have moved to the "symbolic consumption model" within the framework of the global paradigm of consumerism, which is almost the only option for survival of certain phenomena in the post-industrial space, i.e. the "symbolic consumption model" is not a firm evidence of the "extinction" and the gradual disappearance of the decorative and applied arts of the indigenous small-numbered peoples of the north, but, on the contrary, it is a means of adaptation to the conditions of the epoch.

The following step is an attempt to assess the development of the "symbolic consumption model" as regards the decorative and applied arts of the indigenous small-numbered peoples of the Krasnoyarsk Territory North. Here it is worth noting that some peoples of the Krasnoyarsk Territory North are more skilled in terms of creating souvenirs, for example, the Evenks, partly the Dolgans and the Yessei Yakuts, while the souvenir production of other northern peoples is not so developed (partly this concerns the Nganasans and the Selkups who have almost forgotten their arts and crafts). In the future, even within the framework of the "symbolic consumption model" there should be a steady development of arts and crafts by all ethnic groups in the Krasnoyarsk Territory North. Researchers working on the problem of preserving the culture of the indigenous smallnumbered peoples of the Krasnoyarsk Territory North remark that there must be a comprehensive and systemic preservation of the culture of these peoples (their languages, decorative and applied arts, types of land and natural resources use, etc.), while the Krasnoyarsk Territory has not implemented anything of these yet, since the regional north has no tourism infrastructure i, 
which is the vital condition for the prosperity of the decorative and applied arts according to the "symbolic consumption model". No ethnocultural villages have been created, as of today what has only been done is the creation of workshops and business organizations in Taimyr. They make and sell ethnic clothes, bone carving works. Besides, the art centres and museums hold ethnic festivals, where one can buy ethnic souvenirs, attend master classes on the creation of ethnic souvenirs; in schools, where children from the indigenous minorities of the north study, there are educational programs of traditional arts and crafts. This signifies that certain efforts to fully implement the "symbolic consumption model" of the decorative and applied arts of the indigenous northern peoples are undertaken by the regional and local authorities and active representatives of the indigenous peoples, but these efforts are not sufficient for the decorative and applied arts of the indigenous peoples of the Krasnoyarsk Territory North to be adequately represented on the world map.

\section{Scientific modelling ways of arts and crafts effective development of the indigenous small-numbered peoples of the Krasnoyarsk Territory}

Such scientists as Iu.S. Zamaraeva., K.V. Reznikova, N.N. Seredkina, who have a longitudinal experience of expeditions to the places of residence of the indigenous smallnumbered peoples of the Krasnoyarsk Territory North state in detail promising ways of developing decorative and applied arts of the indigenous small-numbered peoples. Among them there are such methods as improving the educational system in terms of decorative and applied arts for the indigenous minorities (introduction of decorative and applied arts courses in school curricula, increase in the number of master classes on decorative and applied arts); organization of private enterprises which produce of various decorative and applied artworks; creation of ethnic parks; research expeditionary work on the study of decorative and applied arts; complex and systemic culture development of the indigenous small-numbered peoples (decorative and applied arts develop together with the language, way of management, folklore, etc.); the utmost return of utility to the objects of the decorative and applied arts of the indigenous peoples of the Krasnoyarsk Territory North or the search for a new application to the works of decorative and applied creativity in modern life, as we saw on the example of mobile phone cases. On the basis of this, we bring in the following scientific model of developing decorative and applied arts of the indigenous small-numbered peoples of the Krasnoyarsk Territory North as "the improvement of the symbolic consumption model” (Fig. 3).

As it was indicated in the previous section, the "symbolic consumption model" for developing the decorative and applied arts of the indigenous small-numbered peoples of the Krasnoyarsk Territory North is relevant and shows potential for existence in a post-industrial society, but at the moment on the Krasnoyarsk Territory North it is implemented only partially, not systemically and not comprehensively, therefore one of the options for developing the decorative and applied arts of the Krasnoyarsk Territory North peoples is to improve and upgrade the current situation. According to the proposed model, we have a three-phase construction: the first level of developing the "symbolic consumption model" - the availability and promotion of souvenirs; the second level of its development is its complex and systemic embodiment in the form of an ethnic park or an ethnocultural village or a whole complex of villages of different nations in the same space; the third level of the "symbolic consumption model" is the promotion of the unique spiritual foundations 
SOUVENIR

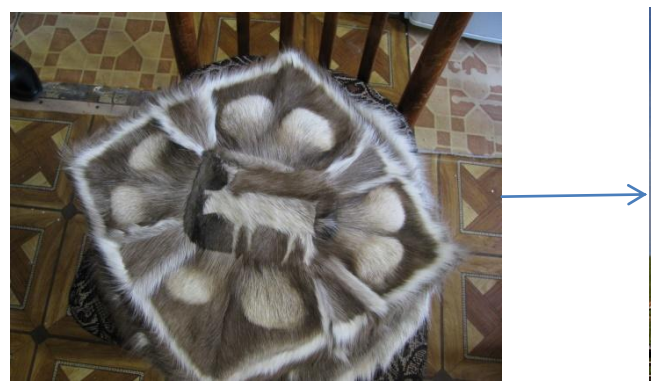

Decorative and applied arts of the indigenous small-numbered peoples of the Krasnoyarsk Territory North as souvenirs. Photo by M. Kolesnik from Yessei, where the Yessei Yakuts live

\section{ETHNO-CULTURAL TOURISM}

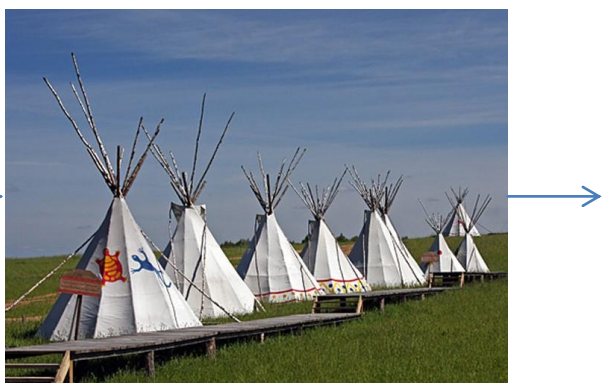

Photo of ethnographic park and museum

"Ethnomir" in the Moscow region.

Source: http://www.kalugaresort.ru/ item/etnomir/

\section{ETHNIC IN MODERN ART}

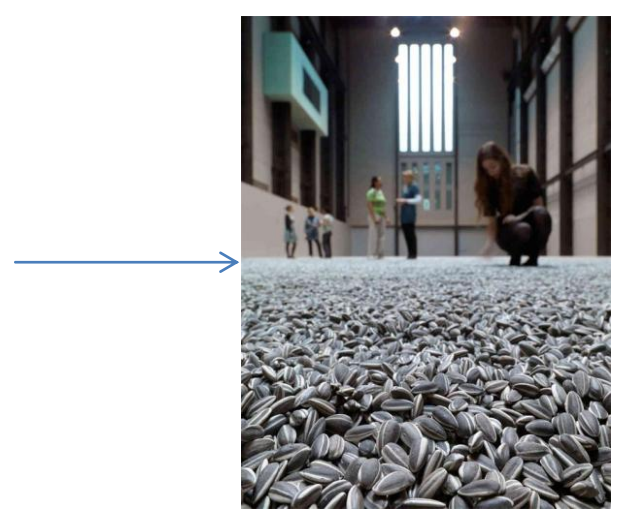

Photo of installation "Sunflower Seeds" by Chinese artist Ai Weiwei in the Turbne Hall atTate modern, London. 2010. Source: https://vilingstore.net/Hudozhnikkonceptualist-Ay-Veyvey-Semena-podsolnuha-i165543

Fig. 3. Model 3. The way of improving the "symbolic consumption model" for developing the decorative and applied arts of the indigenous small-numbered peoples of the Krasnoyarsk Territory North

of ethnic culture by the means of contemporary art. Here it is necessary to clarify that at the first level (souvenirs) we deal with a product that barely has any utilitarian function (as well as a work of art), but shows limited content (the memory about visiting a certain place, reflecting its visual characteristics, some kind of "iconic signs" of the place); at the second level (an ethnic park or an ethnocultural village) we deal with the utmost return of utility to decorative and applied artworks products that are harmoniously intertwined in the national everyday life; finally, at the third level of "symbolic consumption" we focus on creating an artwork, which, on the contrary, is maximally devoid of utilitarianism, but, in comparison with a souvenir, this artwork promotes not the "features of the place", but the complex original emotional and spiritual values of the people, artworks that foster the conversation at the level of "symbolic signs", which is really what the person who lives in the "symbolic consumption system" desires. 
In order to develop the decorative and applied arts of the indigenous small-numbered peoples at every level of the "symbolic consumption model", it is necessary to identify the conditions for this development. Perfection of this model at the level of souvenir production requires, as it was already indicated earlier with reference to other researchers, the improvement of the educational system which will teach the indigenous peoples' decorative and applied arts (the introduction of special courses for indigenous small peoples in the school curriculum; the master classes in museums and on ethnic festivals for children and adults by eminent masters from among indigenous peoples, as well as the creation of the workshops where the outstanding indigenous artists will work, as it is proved that personal training is the best way of transferring the skills of making works of decorative and applied arts; the emergence of special educational directions for design and artistic creation of the indigenous peoples in the universities of large cities of the Krasnoyarsk Territory where students could create works of decorative and applied arts on the basis of local traditions). Next, there should be created private enterprises for the indigenous peoples to make the decorative and applied artworks and to sell them with the use of new modern technologies (websites, translation of their content into English for the promotion of souvenir products on a global level, the use of SMM technologies to market souvenir goods). In the case of souvenirs, it is worth specifying that they will naturally be divided into elite and mass, since products made from natural fur, natural materials (deer hair, bone, etc.) can be created only in limited quantities as complied with the requirement on sustainable use of natural resources, which is inherent in the culture of the indigenous northern peoples, and consequently they will have a much greater value than works of artificial materials, though the latter will also be in demand.

Serious efforts, hardly possible without the administrative support of federal, regional and local authorities, the consent of the indigenous peoples, and the financial support of large industrial corporations, are required for the transition of the decorative and applied arts of the indigenous small-numbered peoples of the Krasnoyarsk Territory to the "symbolic consumption model". The transition to the second level involves the creation of tourism infrastructure on the Krasnoyarsk Territory North, which includes the transport accessibility of the places where the indigenous smallnumbered peoples live, the construction of hotel complexes and interesting places of public catering with dishes of traditional Siberian and polar cuisine. In addition, this strategy implies the artificial construction of a whole ethnocultural complex, representing either the lifestyle of a single northern ethnos (for example, the Evenk village) or the several villages of different ethnoses (the Evenk village, the Dolgan village, the Nganasan village, etc.) like the ethnographic park and museum "Ethnomir" in the Moscow region. The implementation of such a large-scale project will solve the problem with permanent educational master classes on decorative and applied arts (masters could continuously teach their crafts in such villages), organising ethnic festivals where it will be possible to invite a large number of tourists, and, as a result, solve the problem with the souvenir promotion. Perhaps the creation of such a village requires the invention of know-how, an original brand to attract the largest possible number of tourists like the "Ice Hotel" in Sweden. The concept and possibilities for the creation of such an ethnic village in the Krasnoyarsk Territory are only a dream for the time being, so they require detailed elaboration to move in this direction. 
Finally, the third stage of developing the decorative and applied arts of the indigenous small-numbered peoples of the Krasnoyarsk Territory suggests that it is possible to make efforts to ensure that the decorative and applied artworks of the Krasnoyarsk Territory North peoples would get rid of their utilitarian function and turn into the symbolic content of ethnic culture, using symbolic signs and art meanings of the indigenous small-numbered peoples. Such a turn permits us to rethink the possibilities and meanings of the traditional decorative and applied arts in the conditions of the modern world and to find new ways for its development. The transformation of the decorative and applied works of the indigenous peoples of the North into real artworks was analysed by A.A. Semenova and A.V. Bralkova in the article "Visualization of the concept 'The North' in fine arts" (Bralkova, Semenova, 2011), and as such one can consider the work "Sunflower Seeds" by Ai Weiwei, presented in 2010 in the Turbine Hall at Tate Modern in London. Certainly, Ai Weiwei, a modern Chinese artist, cannot be attributed to the masters of decorative and applied art, and his work cannot be called ethnic Chinese art, but this artist often interprets Chinese national and traditional art, translating it into an understandable for international community language, rendering in his works the spiritual concepts of Chinese culture (it does not matter that often in a negative manner, problematizing and provocatively introducing the conceptual foundations of Chinese culture). In the work "Sunflower Seeds" he used porcelain, the traditional material for Chinese art. For many centuries items of decorative and applied arts, for example, vases, have been made of porcelain, and for his installation these were the Chinese masters who made sunflower seeds, which allows us to believe that the author took an advantage of the material component of traditional Chinese decorative and applied arts in order to go on to interpret the symbolic meanings of Chinese culture, as a result of which the entire world art community was forced to study Chinese decorative and applied arts for understanding the Ai Weiwei's ideas. It is assumed that if at least several masters from among the indigenous peoples of the Krasnoyarsk Territory North (who have got traditional education in the field of decorative and applied arts and folk crafts and have been granted training in advanced Russian and foreign educational institutions of the contemporary art) will be able to interpret or highlight the universal and symbolic meanings of the art of the indigenous peoples of the Krasnoyarsk Territory North, this will enable the society to move to a new level of understanding the culture of these peoples. This is a step to more fruitful existence of the decorative and applied arts of the indigenous peoples according to the "symbolic consumption model".

Thus, presumably, the development of the decorative and applied arts of the indigenous small-numbered peoples of the Krasnoyarsk Territory North can be represented by a pyramidal model (Fig. 4).

In conclusion, it should be emphasized that the developed scientific conception of "improving the model of symbolic consumption" for the development of decorative and applied arts of the indigenous small-numbered peoples of the Krasnoyarsk Territory North is probably not the only possible one, being suitable mainly for the system of post-industrial society. Allegedly, a change in the paradigm of the future social development will also affect the changing nature of the development of the decorative and applied arts of the indigenous northern peoples. It seems possible that in case of a change of the dominant consumerism in the society under new environmental challenges, the ancient experience of the indigenous small-numbered peoples of the Krasnoyarsk Territory North will 


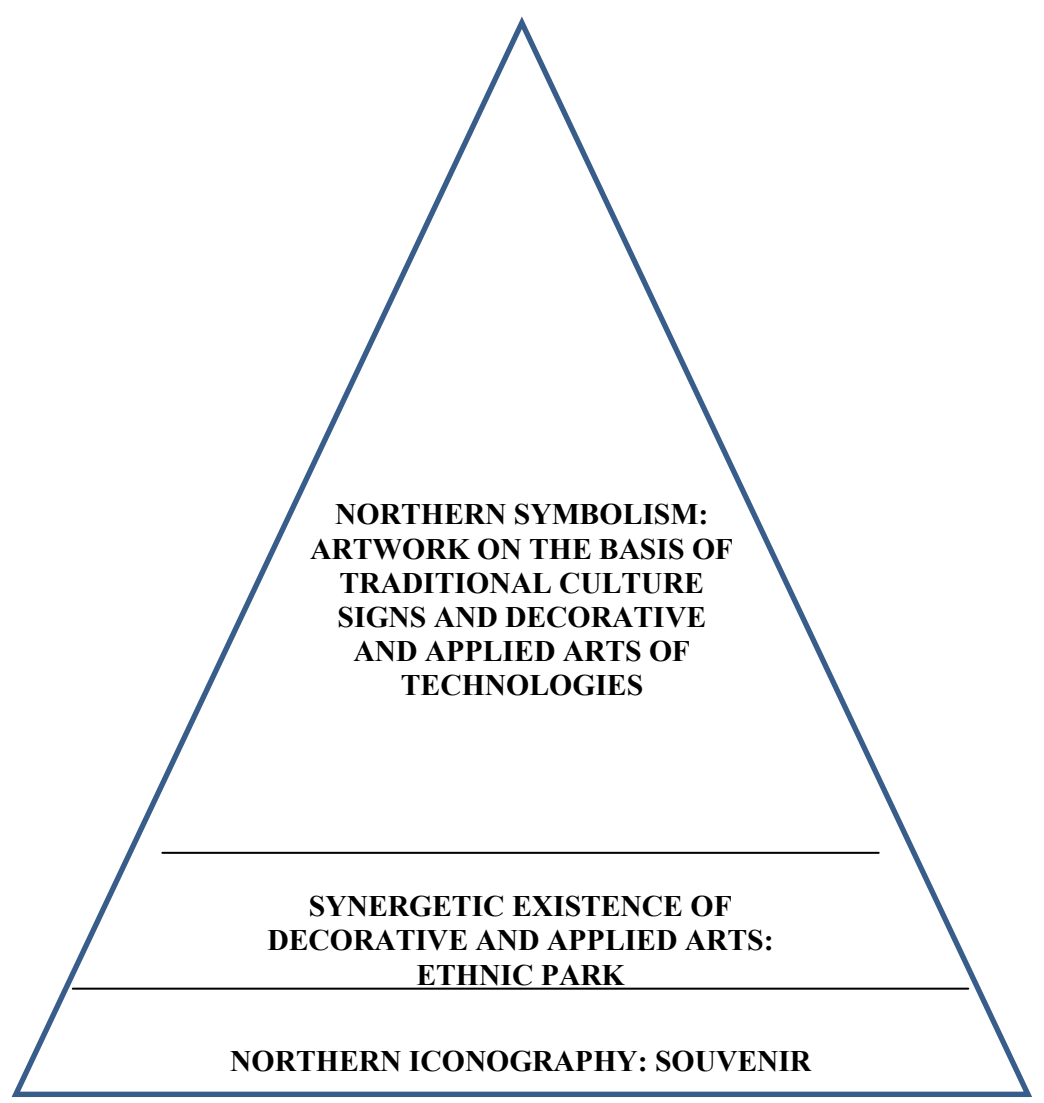

Fig. 4. Model 4. Pyramidal model of developing decorative and applied arts of the indigenous small-numbered peoples of the Krasnoyarsk Territory

be particularly in demand for the ecological, careful and economical use of natural resources, in particular, for the creation of useful household objects necessary for human survival. Thus, the traditional "ecological model" of the existence of the decorative and applied arts of the indigenous northern peoples will be able to manifest itself from the new side and become the mainstream for the development of decorative and applied arts even in urban areas.

\section{Conclusion}

As a result of the study, there were obtained the following results:

1) The authors developed a scientific model of the traditional existence of the decorative and applied arts of the indigenous minorities of the Krasnoyarsk Territory North. This model is called an "ecological model", as it presupposes the sustainable, careful and maximally full use of natural resources by mankind: bone has been used to create beads for decorations and for making durable household objects; fur has been used for tailoring; wood has been used for making utensils and household utensils; veins of animals - for sewing, etc.

2) The current state of decorative and applied arts of the indigenous small-numbered peoples of the Krasnoyarsk Territory North was described as the "symbolic consumption model", as today the main vector of developing the indigenous peoples' decorative and applied arts is the creation of souvenirs (beautiful clothes, beaded panels, dolls, shaman attributes, carved miniatures from bone, mobile phone cases, etc.). 
3) The scientific model of perspective ways of developing decorative and applied arts of the indigenous small-numbered peoples of the Krasnoyarsk Territory North was presented as a three-tier pyramid and was named a "model for improving the system of symbolic consumption", where the first tier is the creation and promotion of souvenirs (the authors listed a number of methods for improving the souvenir production of at this level), the second tier is the synthetic inclusion of the decorative and applied artworks of the indigenous northern peoples in the process of creating ethnocultural villages and ethnic parks (the authors identified basic problems positions that hamper the creation of such ethnic complexes in the Krasnoyarsk Territory); finally, the third tier of developing the decorative and applied arts can be the option of complete renunciation of the utilitarian function in the process for creating artworks based on traditional ornaments, materials or techniques of decorative and applied arts of the indigenous peoples to promote the ethnic cultures' symbolic meanings at the international and universal level.

4) The last thesis of the study is that "themodel of improving the symbolic consumption system" is not the only possible option for the development of decorative and applied arts of the indigenous smallnumbered peoples of the Krasnoyarsk Territory North. It seems possible that according to a new ecological paradigm, the traditional decorative and applied arts' practices of the North indigenous peoples (such as the "ecological model") will be more demanded by the society.

\section{References}

Barabanova, N.A. (2014). Funktsional'naia suschnost' turisticheskogo suvenira [Functional essence of touristic souvenir], In Nauchno-metodicheskii journal "Koncept" [Scientific and methodic journal "Concept"), 20, 4126-4130.

Bralkova, A.V., Semenova, A.A. (2011). Visualization of the Concept "The North" in Fine Arts, In Journal of Siberian Federal University, 4, 4, 476-491.

Curry, J.A., Donker, H., Michel, P. (2016). Social entrepreneurship and indigenous people, In Journal of Co-operative organization and management, 4, 2, 108-115.

Gaidysheva, M., Parniakov, A.V. (2014). Design of applied and decorative art elements based on the example of the Nanai shaman's culture, In Pacific science review, 16, 140-147.

Gavrilov, I.K., Batashev, M.S., Makarov, M.P. (2017). Comprehensive ecological and ethnographic expedition to Evenkia. Nature and man, In Severnye arkhivy $i$ expeditsii [Northern archives and expeditions], 1, 66-83.

Golubchikov, S.N., Pisetskii, E.N., Khetagurova, V.Sh. (2015). Perspectivy razvitiia etnographicheskogo turizma $\mathrm{v}$ Arktike (na primere Berezovskogo raiona Khanty-Mansiiskogo avtonomnogo okruga) [The development prospects for the ethnographic tourism in the Arctic (on the example of Berezovsky district of Khanty-Mansi Autonomous Okrug)], In Sovremennye problemy servisa i turizma [Current Issues of Service and Tourism], 9, 4, 72-78.

Ivanova-Unarova, Z.I. (2005). Traditsionnoe iskusstvo narodov Severo-Vostoka Sibiri (evenki, eveny, yukagiry, dolgany, chukchi, koriaki) [The traditional art of the peoples of North-Eastern Siberia (Evenks, Evens, Yukaghirs, Dolgans, Chukchi, Koryaks)]. Izd-vo YAGU, 192 p.

Koptseva, N.P. (2013). The results of theoretical and experimental research of the modern problems of the indigenous small-numbered peoples of the North, Siberia and the Far East in Siberian Federal University, In Journal of Siberian Federal University. Series: The Humanities, 6 (5), 762-772. 
Koptseva, N.P., Kirko V.I. (2014). Specificity of ethnogeny of the indigenous peoples in Central Siberia in the transition from the traditional type of society to modern society, In Life Science Journal, 11 (7), 409-413.

Koptseva, N.P., Amosov, A.E., Kirko, V.I., Libakova, N.M., Reznikova, K.V., Sertakova, K.V., Pimenova, N.N., Kistova, A.V., Bokova, V.I., Semenova, A.A. (2012). Korennye malochislennnye narody Severa i Sibiri v usloviiakh global'nykh transformatsii (na materiale Krasnoiarskogo kraia). Chast' 1. Kontseptual'nye i metodologicheskie osnovy issledovaniia. Etnokul'turnaia dinamika korennykh malochislennykh narodov Krasnoiarskogo kraia [The indigenous small-numbered peoples of the North and Siberia under the global transformations (on the material of the Krasnoyarsk Territory). Part 1. Conceptual and methodological foundations of the study. Ethnocultural dynamics of the indigenous small-numbered peoples of the Krasnoyarsk Territory]. Krasnoyarsk, Siberian Federal University, $640 \mathrm{p}$.

Koptseva, N.P. (2013). K voprosu o sokhranenii i vosproizvodstve traditsionnoy kul'tury korennykh malochislennykh narodov Severa, Sibiri i Dal'nego Vostoka v Sibirskom federal'nom okruge [On preservation and reproduction of traditional culture of the indigenous minorities of the North, Siberia and the Far East in Siberian Federal District], In Sotsiodinamika [Sociodynamics], 12, 1-16.

Koptseva, N.P., Nevol'ko, N.N. (2012). The national visual art in the process of formation and preservation of ethnic identity of the indigenous peoples (on the example of Khakass visual art), In Journal of Siberian Federal University. Series: The Humanities, 5 (8), 1179-1198.

Koptseva, N.P., Nevol'ko, N.N., Reznikova, K.V. (2013). Formirovanie etnicheskoi kul'turnoi identichnosti v sovremennoi Rossii s pomoshch'iu proizvedenii natsional'nogo iskusstva (na primere Evenkiiskogo eposa i dekorativno-prikladnogo iskusstva) [Formation of ethnic cultural identity in modern Russia with the help of works of national art (on the example of the Evenki epos and arts and crafts)], In Pedagogika iskusstva [Pedagogy of Art], 1, 1-15.

Koptseva, N.P., Pimenova, N.N., Seredkina, N.N. (2013). Izuchenie dekorativno-prikladnogo iskusstva i traditsionnykh religii korennykh malochislennykh narodov Severa kak faktor formirovaniia pozitivnoi obshcherossiiskoi kul'turnoi identichnosti [Study of arts and crafts and traditional religions of the indigenous minorities of the North as a formation factor of a positive all-Russian cultural identity], In Pedagogika iskusstva [Pedagogy of Art], 2, 15-30.

Kudashkin, V.A., Kiryutkin, S.A. (2016). Khudozhestvennaia intelligentsiia korennykh malochislennykh narodov Taimyra i ee vklad v razvitie ehtnicheskoi kul'tury v 1990-2000-e gg. [Art intelligentsia among the indigenous minorities of Taimyr and their impact on the ethnic cultural development in 1990s-2000s], In Problemy sotsial'no-ekonomicheskogo razvitiia Sibiri [Problems of socio-economic development of Siberia], 2, 85-89.

Libakova, N.M. (2015). Formirovanie pozitivnoi etnicheskoy identichnosti indigennykh narodov posredstvom dekorativno-prikladnogo iskusstva (rez'ba po kosti) [The formation of positive ethnic identity of the indigenous peoples through arts and crafts (bone carving)], In Sovremennye problemy nauki i obrazovaniia [Modern problems of science and education], 1 (1), 750-768.

Libakova, N.M., Kolesnik M.A., Sertakova E.A., Sergeeva N.A. (2017). Issledovatel'skie vozmozhnosti antropologii iskusstva na primere kostoreznykh proizvedeniy masterov Sibiri [Research opportunities for art anthropology on the example of Siberian masters' bone carving works], In Sibirskii antropologicheskii jurnal [Siberian anthropological journal], 1 (06), 22-34. 
Lomanova, T.M. (2015). Mir preobrazhennykh rukami masterov. Dekorativno-prikladnoe iskusstvo Krasnoiarskogo kraia [The world is transformed by craftsmen. Decorative arts of the Krasnoyarsk Territory]. Krasnoyarsk.

Pimenova, N.N. (2014). Evenkia's craftsmen. Creative heritage. JSC Rosneftegaz, 120 p.

Pimenova, N.N. (2014). Kul'turnoe nasledie korennykh malochislennykh narodov Krasnoiarskogo kraia i sovremennye kul'turnye praktiki [The cultural heritage of the indigenous minorities of the Krasnoyarsk Territory and modern cultural practices], In Chelovek i kul'tura [Man and culture], 2, 28-66.

Reznikova, K.V. (2010). Current studies of the Selkups residing in Krasnoyarsk Krai based on field studies, In Severniye arkhivi i expeditsii [Northern archives and expeditions], 1, 23-24.

Rodionov, G. N. (2007). Kostoreznoe iskusstvo Arktiki [Bone-carving art of the Arctic], In Vestnik Severo-Vostochnogo universiteta imeni M.K. Ammosova [Bulletin of North-Eastern Federal University named after M.K. Ammosov], 4, 110-112.

Sorokina, S.A., Chernyshova, S.L. (2014). Traditsii prepodavaniia dekorativno-prikladnogo i tantseval'no-muzykal'nogo iskusstva narodov severa v RGPU im. A.I. Gertsena: razvitie sovremennogo obrazovaniia: teoriia, metodika i praktika [The tradition of teaching arts and crafts and dance-musical art of the peoples of the North in Russian State Pedagogical University named after A.I. Herzen: development of modern education: theory, methodology and practice], In TsNS "Interaktiv plius", Cheboksary, 12-25.

Totonova, E.E. (2015). Razvitie kooperativov na Severe: opyt Kanady [The development of cooperatives in the North: the Canadian experience], In Upravlenie ekonomicheskimi sistemami [Economic systems management], 9 (81), 1-10.

Varavina, G.N. (2016). Ornamental art of the indigenous people of the Arctic: traditions and the present (based on the Evens and the Evenki), In Journal of Siberian Federal University. Series: Humanities, 9 (10), 2525-2530.

Vukvukai, N.I. (2012). Dekorativno-prikladnoe iskusstvo na Chukotke: istoriia i perspektivy razvitiia [Decorative arts in Chukotka: history and prospects], In Gumanitarnye issledovaniia v Vostochnoi Sibiri i na Dal'nem Vostoke [Humanities studies in East Siberia and the Far East], 1 (17), 139-146.

Zolotareva, N.V., Kuryanova, T.S., Ryndina O.M. (2013). Kapitalizatsiia kul'turnogo naslediia narodov Zapadnoi Sibiri [The capitalization of the cultural heritage of the indigenous peoples of Western Siberia], In Vestnik Tomskogo gosudarstvennogo universiteta [Bulletin of Tomsk State University], 371, 49-57.

Zulaikha, E., Brereton, M. (2011). Innovation strategies for developing the traditional souvenir craft industry, In Queensland University of Technology, Brisbane, Qld., 53-58. 


\section{Научное моделирование современного состояния \\ и способов эффективного развития \\ декоративно-прикладного искусства \\ коренных малочисленных народов \\ Красноярского края}

М.А. Колесник, А.А. Ситникова

Сибирский федеральный университет

Россия, 660041, Красноярск, пр. Свободный, 79

В статье представлена научная модель традиционного бытования ДПИ коренных народов Красноярского края, которая обозначена как «экологическая модель», так как предполагает бережное и экономное использование всех добытых человеком природных ресурсов. Разработана научная модель современного состояния ДПИ коренных малочисленных народов Севера Красноярского края, которая обозначена как «модель символического потребления», проанализированы основные типы сувенирной продукции коренных малочисленных народов Севера Красноярского края - вышивка бисером, косторезное искусство, пошив праздничной одежды, таксидермия, шаманские атрибуты, куклы-обереги и др. Предложена научная модель способов эффективного развития ДПИ коренных малочисленных народов Севера Красноярского края, которая предполагает совершенствование системы «символического потребления» сначала на уровне сувенирных производств, далее на уровне создания этнокультурных деревень и этнопарков, и, наконеи, на уровне создания произведений современного искусства, понятных и интересных на международном уровне.

Ключевые слова: декоративно-прикладное искусство, коренные малочисленные народы, сувениры коренных народов Севера, этнопарк, модели развития ДПИ коренных народов Севера.

Исследование выполнено при поддержке краевого государственного автономного учреждения «Красноярский краевой фонд поддержки научной и научно-технической деятельности» в рамках реализачии проекта: "Декоративно-прикладное искусство коренных малочисленных народов Красноярского края: современное состояние, перспективы развития.

Исследование выполнено при финансовой поддержке Российского фонда фундаментальных исследований, Правительства Красноярского края, Красноярского краевого фонда поддержки научной и научно-технической деятельности в рамках научного проекта № 17-16-24601.

Научная специальность: 24.00.00 - культурология. 